\title{
Investigating the functional role of the oestrogen receptor in LY2 endocrine resistant breast cancer cells
}

\author{
Chrisen Ramkaran ${ }^{1 *}$, Alacoque Browne ${ }^{2}$, Leonie Young ${ }^{2}$ \\ From 4th International Conference for Healthcare and Medical Students (ICHAMS) 2014 \\ Dublin, Ireland. 24-25 October 2014
}

\section{Background}

The issue of acquired resistance to breast cancer regimes such as tamoxifen continues to negatively affect clinical outcomes. While many mechanisms of resistance have been discovered $[1,2]$, there is evidence now of acquired resistance through adaptation of the oestrogen receptor itself leading to tumour progression [3]. A thorough understanding of the processes involved in the receptor's adaptation remains unclear. This study gives evidence of the gene signalling which shed light on the mechanism of adaptation in an LY2 endocrine resistant cell line oestrogen receptor knockdown model.

\section{Methods}

Real time PCR examines the gene expression profile of the LY2 cells under various treatments including oestrogen, tamoxifen and a mixture of both.

\section{Results}

It was found that the normal oestrogen receptor target genes PS2 and GREB1 display reduced expression without the presence of the receptor. However EGR3 signals excessively despite having the receptor stably knockdown.

\section{Conclusions}

As a result these data provides evidence that EGR3 is involved in the adaptation of the oestrogen receptor and that global signalling of common target genes does not occur when the receptor adapts. Hence it demonstrates an initial clue of the process of adaptation in resistant tumours that have changed their receptor status.

\author{
Authors' details \\ ${ }^{1}$ Royal College of Surgeons in Ireland, Dublin, Ireland. ${ }^{2}$ Endocrine Oncology \\ Research Group, Dept of Surgery, Royal College of Surgeons in Ireland, \\ Dublin, Ireland. \\ Published: 27 October 2015

\section{References} \\ 1. García-Becerra R, Santos N, Díaz L, Camacho J: Mechanisms of Resistance \\ to Endocrine Therapy in Breast Cancer: Focus on Signaling Pathways, \\ miRNAs and Genetically Based Resistance. Int J Mol Sci 2012, \\ 14(1):108-145. \\ 2. Normanno N, Di Maio M, De Maio E, De Luca A, de Matteis A, Giordano A, \\ et al: Mechanisms of endocrine resistance and novel therapeutic \\ strategies in breast cancer. Endocr Relat Cancer 2005, 12(4):721-747. \\ 3. Vareslija D MJ, Fagan A, Redmond A M, Hao Y, O'Gaora P, Hill ADK, \\ Young LS: Adaptation to Al therapy in breast cancer can induce dynamic \\ alterations in ER activity resulting in estrogen independent metastatic \\ tumours. Clinical Cancer Research .
}

doi:10.1186/1753-6561-9-S7-A27

Cite this article as: Ramkaran et al:: Investigating the functional role of the oestrogen receptor in LY2 endocrine resistant breast cancer cells. BMC Proceedings 2015 9(Suppl 7):A27.

${ }^{1}$ Royal College of Surgeons in Ireland, Dublin, Ireland

Full list of author information is available at the end of the article

Submit your next manuscript to BioMed Central and take full advantage of:

- Convenient online submission

- Thorough peer review

- No space constraints or color figure charges

- Immediate publication on acceptance

- Inclusion in PubMed, CAS, Scopus and Google Scholar

- Research which is freely available for redistribution
C Biomed Central

C 2015 Ramkaran et al. This is an Open Access article distributed under the terms of the Creative Commons Attribution License (http:// c 2015 Ramkaran et al. This is an Open Access article distributed under the terms of the Creative Commons Attribution License (http://
creativecommons.org/licenses/by/4.0), which permits unrestricted use, distribution, and reproduction in any medium, provided the original work is properly cited. The Creative Commons Public Domain Dedication waiver (http://creativecommons.org/publicdomain/ zero/1.0/) applies to the data made available in this article, unless otherwise stated. 